\title{
Quest for a Valid Phillips Curve in the Long Run: An Empirical Approach
}

\author{
Mohammed Saiful Islam ${ }^{1}$, Riduanul Mustafa ${ }^{2}$ \\ ${ }^{1}$ Professor, Department of Economics, Chittagong University, Bangladesh \\ ${ }^{2}$ Lecturer - Economics, School of Business, Bangladesh Army International University of Science and \\ Technology, Comilla, Bangladesh \\ Correspondence: Mohammed Saiful Islam, Professor, Department of Economics, Chittagong University, \\ Bangladesh.
}

Received: April 17,2015

doi:10.5539/ibr.v10n4p191

\author{
Accepted: August 1,2016 \\ Online Published: March 28, 2017 \\ URL: https://doi.org/10.5539/ibr.v10n4p191
}

\begin{abstract}
This paper examines the relationship between inflation rate (percentage change in consumer price index) and unemployment rate (number of unemployed persons as a percentage of the labor force) by using modern econometric approach to find a "Phillips Curve". Using US data of both monthly and yearly frequency, the paper finds the existence of a long-run trade-off between inflation and unemployment. A linear form of the Phillips curve is estimated for the USA using ordinary least squares estimation (OLS). The co integration test shows the long run relation between the variables. This contradicts the theory that in long run the Phillips curve should be vertical. Some of the findings can be summarized as follows: (a) the Phillips Curve fits the data well; (b) inflation of previous year influences the present rate of inflation and (c) both monthly data and yearly data support the existence of Phillips curve in the long run
\end{abstract}

Keywords: inflation, unemployment, consumer price index, Phillips curve

\section{Introduction}

The Phillips curve is named after a single-equation empirical model built by A.W.H. Phillips (1958). The model relates wages negatively to unemployment. Based on a scattered diagram of the two time series data using the UK annual data for the period 1861-1957 net of the interwar period, Phillips conjectured a hyperbolic function between the growth rate of wages and unemployment rate. In an economy, it is the study of inverse relationship between the rate of unemployment and the rate of inflation either short run or long run. Phillips and Samuelson-Solow drew curves through the inflation and unemployment data; they used these as structural relations to discuss a long-run Phillips curve trade-off between inflation and unemployment. There are three assumptions of Phillips curve; first one is, in short run, there is tradeoff between inflation and unemployment. Second, aggregate supply shock can break the concept of Phillips curve because it can cause both higher rate of inflation and unemployment which is also known as stagflation. Third, in long run there is no significant tradeoff between inflation and unemployment. Therefore economists have massive interest to identify their relationship; there is a short run tradeoff between the rate of inflation and unemployment, (McConnell, 16th ed). In this regard it has been also seen in many studies that there is short run tradeoff between inflation and unemployment in different countries in different time periods. Though, the rate of low inflation and low unemployment are major economic goals. But it is not possible to achieve both economic goals (low inflation and low unemployment) simultaneously. Inflation is the concern of monetary policy while unemployment is of fiscal policy. The aim of monetary policy is to control the level of inflation or to maintain the sustainable inflation in the economy by sacrificing employment. In contrast, the goal of fiscal policy is to make low unemployment in the economy at any rate of inflation. Therefore, coordination among the policies is very important in order to maintain optimal level of tradeoff between inflation and unemployment.

Basically, the term inflation refers to increase in overall price level of goods and services in the economy which leads to decrease in the purchasing power of household. Because whenever prices will increase, the value of money will be depreciated and ultimately the real income of household will decrease. Usually it is assumed that increase in prices of goods and services are just like decrease in income and vice versa. 
The definition of unemployment is that the condition in the economy when supply of labor exceeds the demand for labor in the labor market of the economy. Simply, a person who is willing to do the job but due to shortage of the jobs he or she could not find the job in the economy is known as unemployment.

In this study, we will investigate whether inflation rate and unemployment rate are associated with each other or not in short-run and long-run and if they are then whether it is positive or negative. The rest of the paper is organized as follows. Section 2 documents the objective of the research, section 3 reviews literature, section 4 states the source of data and depicts the methodology. Section 5 presents empirical results and their implication and finally section 6 concludes.

\section{Objective of the Study}

There is an age-old debate regarding the relationship between inflation and unemployment. On the basis of actual data, Phillips (1958) confirms an inverse relationship between inflation and unemployment. The macroeconomic mechanism of such inverse relation is very much straightforward. Increase in inflation reduces the real rate of wage that is likely to increase the demand for labour. Increase in the demand for labour results in higher employment and thereby low rate of unemployment. This inverse relationship between inflation and unemployment has later become known as Phillips Curve relationship. Since the inception of this law, a wide volume of researches has been carried out on the issue. Some of the researchers have come up with the conclusion that the inverse relation between inflation and unemployment is a short-run phenomenon. In the long-run the inverse relation rather disappears. As opposed to the downward sloping Phillips curve on inflation and unemployment plane, the latter school advocates a vertical Phillips curve in the long run. In this paper our main objective is to examine the Phillips relation in the long run. Using monthly and yearly US data, we examine the existence of original Phillips relation in the long run.

\section{Literature Review}

Numerous researchers have conducted research to find out trade-off between inflation and unemployment. But we will only discuss and review those papers that used econometric approach and those have the similarities with our works. We also review some major paper and empirical works. Some of them are mentioned in this paper.

A.W. Phillips who became famous for his work entitled "The Relationship between Unemployment and the Rate of Change of Money Wage Rates in the United Kingdom 1861-1957" in 1958. According to him, there was a strong negative association between unemployment and inflation in his study. This trade-off relationship was named by him as Phillips curve. From the time William Phillips made this pronouncement in the end of the 1950s, a lot of research studies have been done with a purpose of either to confirm or to refute his work.

Paul Samuelson and Robert Solow were the very first researchers who supported the Phillips hypothesis abo ut the negative association between unemployment and inflation. Samuelson and Solow (1970) examined the relationship between the two macroeconomics variables in the context of the United States. The results led to a conclusion that there existed an inverse relationship between unemployment and inflation rates in the USA. Furthermore, Solow (1970) and Gordon (1971) confirmed the existence of a negative trade-off relationship between unemployment and inflation using U.S. macroeconomic data. These empirical findings have been known as the "Solow-Gordon affirmation" of the Phillips curve. This paper finds an empirical evidence of their findings, and agreed with them about negative relationship between unemployment and inflation. Milton Friedman (1968) and Edmund Phelps (1967) openly criticized the hypothesis and maintained that there is no trade-off between unemployment and inflation. Furthermore, Lucas (1976) strongly opposed the proposition of the existence of the Phillips curve. The workers would foresee the high inflation in the future and would demand wage increase from their employers. In this case, there could be coexistence of high unemployment and high inflation rate which is known as the "Lucas Critique". But this paper opposes the findings of Friedman, Phelps and Lucas as it finds the negative association while conducting estimation. However Jeffrey (1995) Assistant Vice President and Economist, Federal Reserve Bank of Boston discuss briefly upon the history of Phillips curve. His writing was a criticism of "federal bank of Boston conference, 1978". Most papers of this conference were sounded the knell death of Phillips curve. But this paper shows that it is still (1995) alive and well. Perry (1960) included lags of the consumer price index as adjustment for the cost of living in his wage price Phillips curve. Klein and Goldberger (1955) in their model includes an equation that makes the change in wage a function of the unemployment rate and lagged change in the price level. John Dinar do and Mark Moore (1999) used panel data analysis to examine 9 member countries of the" Organization for Economic Co-operation and Development" (OECD). The researchers used the method of Ordinary Least Squares (OLS) and Generalized Least Squares (GLS). Their findings confirmed the existence of the "common" Phillips curve in these OECD countries. As Dinar do and Moore concluded, "In sum, we believe that our results show a remarkable robust relationship 
between relative inflation and relative unemployment". As this paper use Ordinary Least Square (OLS) method and find the negative association, it also confirms the presence of a Philips curve. Fatima Shad man (1996) used Johansen's maximum likelihood method of testing for co integration; a long-run inverse relationship is indeed depicted between the rate of inflation and the unemployment rate. However, the main impact of deviations from this long-run equilibrium is on the unemployment rate rather than the rate of inflation. This work is also having similarities with our work. Turner and Seghezza (1999) also employed the panel data method. They examined the Phillips curve in 21 OECD countries over the period from the early 1970s to 1997. To analyze the pooled data, Turner and Seghezza used the method of Seemingly Unrelated Estimation (SURE) rather than the OLS. The researchers concluded that the overall result provided a "strong support" for the existence of the "common" Phillips curve among the 21 chosen member countries of OECD. This paper also agreed with them. But the difference is that, we use data of U.S.Ainstead of OECD countries. Hassler and Neugart (2003), Aguair, Meneul and Martinst (1997) works on the linearity of the Phillips curve and explains that Phillips curve is linear and also statistically significant. They find trade-off between inflation and unemployment in their work but Okun law shows some non lineararity. But his work was not statistically significant. Berger (2010) found that increase in cyclical unemployment will lead to decrease in output which ultimately causes to decrease in inflation. The New Keynesian Phillips Curve incur orates forward looking behavior of inflation. (Fuhrer and Moore,1995; Roberts, 1995). Inflation contains important low-frequency variation, as captured by a "unit root" stochastic process, then one can estimate long-run trade-offs using procedures like those of Gordon and Solow. Further, these types of estimates can be large even after 1970, as shown in (King and Watson, 1992). Watson (1994) used monthly data in his paper and found evidence that there is a pronounced negative correlation of inflation and unemployment at business cycle frequencies which is remarkably stable over the post war period lower frequencies of inflation \& unemployment. However this links are very unstable across time. Marika and Dennis (2002) in their paper stated that when the time discount rate is positive, the backward looking determinants of wage formation have a stronger influence than the forward looking ones. (ii) Hence an increase in money growth raises the inflation rate and reduces the unemployment rate in the long run; the long-run Phillips curve is downward-sloping. Ann-Charlotte Eliasson (2001) tested the linearity and parameter constancy of Phillips for Australia, Sweden and the United States The nonlinear alternative is specified as a smooth transition regression model. It turns out that linearity is rejected for both Australia and Sweden while the Phillips curve for the United States appears to be linear. The current paper also finds the evidence of linear Phillips curve for United States. Jordi Galí and J David López-Salido (2010) provides evidence on the fit of the new Phillips curve for Spain over the most recent disinflationary periods (1980-1998) then in Spain. This paper has pointed out two things (1) the npc fits data well (2) the backward looking componant of inflation is important.This paper introduces us with a new concept of phillips curve "New Phillips Curve (NPC)". New phillips curve based on staggered nominal price setting, in the spirit of Taylor's (1980) seminal work. Difference of NPC with traditional Phillips curve is that price changes are the result of optimizing decisions by monopolistically competitive firms subject to constraints on the frequency of price adjustment where traditional phillips curve relates inflation to some cyclical indicator plus lagged value of inflation. This paper also reveals that it is possible to find some evidence of a phillips curve relationship which explicitely emphasized the link between inflation and unemployment. Ricardo (2005) in an econometric approach shows a new specification of phillips curve that contains different unemployment lengths in a time varing NAIRU (non accelerating inflation rate of unemployment) settings, and finds that unemployment duration matters in the determination of prices and wages. Fumitaka Furuoka (2007) finds an empirical evidence to report the existence of the Phillips curve in the case of Malaysia. The most interesting findings of this paper is the existence of a long run trade off relationship and also causal relationship between the unemployment rate and the rate of inflation in Malaysia. Pami Dua (2009) analyzed the economic variables of eight Asian countries and found that output gap is significant in explaining inflation rate. For all countries the forward looking Phillips curve better fits. Imtiaz, Osmanand and Nayaz (2011) observed positive relation between inflation \& unemployment for Pakistan \& negative relation for Bangladesh while they observed no relation for India \& Srilanka. Hasan (2012) works on the determination of inflation within the framework of Phillips curve and investigates whether there exist any relationship between these two. This paper has provided an empirical evidence to support the existence of Phillips curve in the case of Bangladesh. Gary Koop and Luca (2012), using theoretical structures based on the new Keynesian and neo-classical Phillips curve and applying both regression and VAR-based model, finds that there have been shift in the Phillips curve and identifies three sub periods in emu. Smith (2006) in his paper observed a Phillips curve for Japan which looks like Japan. He indeed took his inspiration from (Brauce, 2003). Daly and Hobijn(2014)introduce a model of monetary policy with downward nominal wage rigidities and showed that both the slope and curvature of the Phillips curve depend on the level of inflation and the extent of downward nominal wage rigidities. Kumar and Orrenius (2015) find the mixed 
evidence of non-linearitywith some recent studies either rejecting nonlinearity or estimating only modest convexity while they estimating the Phillips curve for U.S. they find strong evidence that the wage-price Phillips curve is nonlinear and convex.

From the review of above literatures it is observable that though theoretically long run Philips curve is vertical, but there is empirical evidence of long run downward sloping Phillips curve. It means even in the long run there exists a trade-off between rate of inflation and rate of unemployment.

\section{Data and Methodology}

\subsection{Source of Data}

The data have been taken from online resources. This paper examines the relationship between inflation rate (percentage change in consumer price index) and unemployment rate (number of unemployed persons as a percentage of the labor force) in U.S.A. In the whole process we use data from online resource including metadata (It is often referred to as data about data or information about data because it provides data users with information about the purpose, processes, and methods involved in the data collection). For U.S.A we use monthly data of inflation and unemployment from the January, 1973 to May, 2012. All data sources are given at the end of the paper.

\subsection{Modeling Phillips Curve}

In this paper, we follow the model developed by Perry (1960) who included lags of the consumer price index as adjustment for the cost of living in his wage price Phillips curve. We use inflation rate $\left(\operatorname{In} f_{t}\right)$ as the percentage change in consumer price index as dependent variable. Our independent variables are unemployment rate $\left(U n_{t}\right)$ percentage of share of labor force without work but available for and seeking employment and previous year inflation or lagged inflation $\left(I n f_{t-1}\right)$. All these variables are taken in this paper in order to examine the Phillips curve for selected countries. The simple Phillips curve could be estimated by using following equation:

$$
\text { Inf } f_{t}=\beta_{1}+\beta_{2} U n_{t}+\beta_{3} \operatorname{Inf} f_{t-1}+\varepsilon_{t} \ldots \ldots \ldots \ldots \ldots \ldots
$$

$\beta_{1}$ is constant and $\beta_{2}$ and $\beta_{3}$ are slope coefficient and $\varepsilon_{t}$ is the error term. We used software E-Views for conducting all the estimations and tests necessary for this paper. In the first stage of the study, in order to assess the Phillips curve, unit root test is used to examine the stationary of data sets. The current paper uses the augmented Dickey-Fuller (ADF) unit root test to find out the stationary data (Dickey and Fuller 1979, 1981). Then in the second stage we have conducted the estimation of equation 1.Then we check the estimation result. After having all the expected sign in the estimation output, we then in the third stage conducted the unit root test again for the residual to investigate whether the variable are co integrated or not. After having confirmation of co integration, we will check the correlation coefficient between the independent variables to find out the existence of multicollinearity. If multicollinearity exists in the model we have to mitigate this. Finally we carry out the tests for checking stability. In this paper we use Ramsey RESET test. It shows us our model is correctly specified or not.

\section{Empirical Findings}

\subsection{Unit Root Test for Inflation}

In this section we observe the unit root test result for our inflation series for U.S.A. Then we will observe the probability value of the t-statistic. Which will guide us to decide whether the series "inflation" is stationary or not. If we can reject null, it will mean that "inflation" don't have a unit root. That is the series is stationary.

\begin{tabular}{|c|c|c|c|}
\hline \multicolumn{4}{|c|}{$\begin{array}{l}\text { Null Hypothesis: inflation has a unit root } \\
\text { Lag Length: } 15 \text { (Automatic based on SIC, MAXLAG=17) }\end{array}$} \\
\hline & & t-Statistic & Prob.* \\
\hline \multicolumn{2}{|c|}{ Augmented Dickey-Fuller test statistic } & -3.517118 & 0.0387 \\
\hline Test critical values: & $\begin{array}{l}1 \% \text { level } \\
5 \% \text { level } \\
10 \% \text { level }\end{array}$ & $\begin{array}{l}-3.978266 \\
-3.419686 \\
-3.132458\end{array}$ & \\
\hline
\end{tabular}

Here in the ADF unit root test t-statistic value is -3.517 (prob-0.0387). We can see from the above table that the critical value at $5 \%$ level is -3.419 .So, we can reject the null $\left(H_{0}\right)$ that, inflation has a unit root. That is why the series is stationary.

\subsection{Unit Root Test for Unemployment}

In this subsection we observe the unit root test result for our unemployment series for U.S.A. in order to decide 
whether the series "Unemployment" is stationary or not. If we can reject null, it will mean that "Unemployment" don't have a unit root. That is the series is stationary.

Null Hypothesis: unemployment has a unit root

Lag Length: 4 (Automatic based on SIC, MAXLAG=17)

\begin{tabular}{llll}
\hline \multicolumn{2}{l}{} & t-Statistic & Prob.* \\
\hline Augmented Dickey-Fuller test statistic & -2.823622 & 0.0557 \\
Test critical values: & 1\% level & -3.444098 & \\
& $5 \%$ level & -2.867496 & \\
& $10 \%$ level & -2.570005 & \\
\hline
\end{tabular}

*MacKinnon (1996) one-sided p-values.

Here in the ADF unit root test t-statistic value is -2.824(prob: 0.0557).We can see from the above table that the critical value at $5 \%$ level is -2.867 . So we cannot reject null at $5 \%$ level. But it is not near to $5 \%$ level. So we will consider the $10 \%$ level. As this is marginally miss the $5 \%$ level we will accept this at $10 \%$ level. So we can reject the null $\left(H_{0}\right)$ that, unemployment has a unit root. That is the series is stationary.

\subsection{Estimation Output of Equation 1}

Now we are ready to estimate our equation (1) by using E-Views we find the following result.

\begin{tabular}{|c|c|c|c|c|}
\hline \multicolumn{5}{|c|}{ Dependent Variable: INF } \\
\hline Variable & Coefficient & Std. Error & $\mathrm{t}$-Statistic & Prob. \\
\hline$\overline{\mathrm{C}}$ & 0.306439 & 0.082536 & 3.712820 & 0.0002 \\
\hline UN & -0.043777 & 0.012127 & -3.609770 & 0.0003 \\
\hline INF_LAG & 0.993494 & 0.006291 & 157.9274 & 0.0000 \\
\hline R-squared & 0.981645 & \multicolumn{2}{|c|}{ Mean dependent var } & 4.436229 \\
\hline Adjusted R-squared & 0.981567 & \multicolumn{2}{|c|}{ S.D. dependent var } & 3.095127 \\
\hline S.E. of regression & 0.420219 & \multicolumn{2}{|c|}{ Akaike info criterion } & 1.110255 \\
\hline Sum squared resid & 82.81798 & \multicolumn{2}{|c|}{ Schwarz criterion } & 1.136677 \\
\hline Log likelihood & -259.0202 & \multicolumn{2}{|c|}{ Hannan-Quinn criter. } & 1.120648 \\
\hline F-statistic & 12541.53 & \multicolumn{2}{|c|}{ Durbin-Watson stat } & 1.258872 \\
\hline Prob(F-statistic) & 0.000000 & & & \\
\hline
\end{tabular}

If we analyze the result of estimation, we can see a clear trade-off between unemployment and inflation in the long run. It is also noticeable that the probabilities of the coefficients are very significant. The R-Square is 0.98 which is also significant. The probability of $\mathrm{F}$ statistic is also seems statistically significant. Here the coefficient of the constant is 0.306439 , the coefficient of independent variable unemployment is -0.043777 and the coefficient of inflation lag is 0.9934 . So dependent variable inflation is negatively related with unemployment, and lagged value of inflation has a strong influence on current inflation (see appendix for related graphs). So the Estimated model is:

$$
\text { Inf } f_{t}=0.30640-0.0438 U n_{t}+0.9934 \operatorname{In} f_{t-1}+\widehat{\epsilon}_{t} \ldots \ldots \ldots
$$

But before we conclude we have to test the residual by a unit root for ensuring the co integration between the variables the result looks like the following-

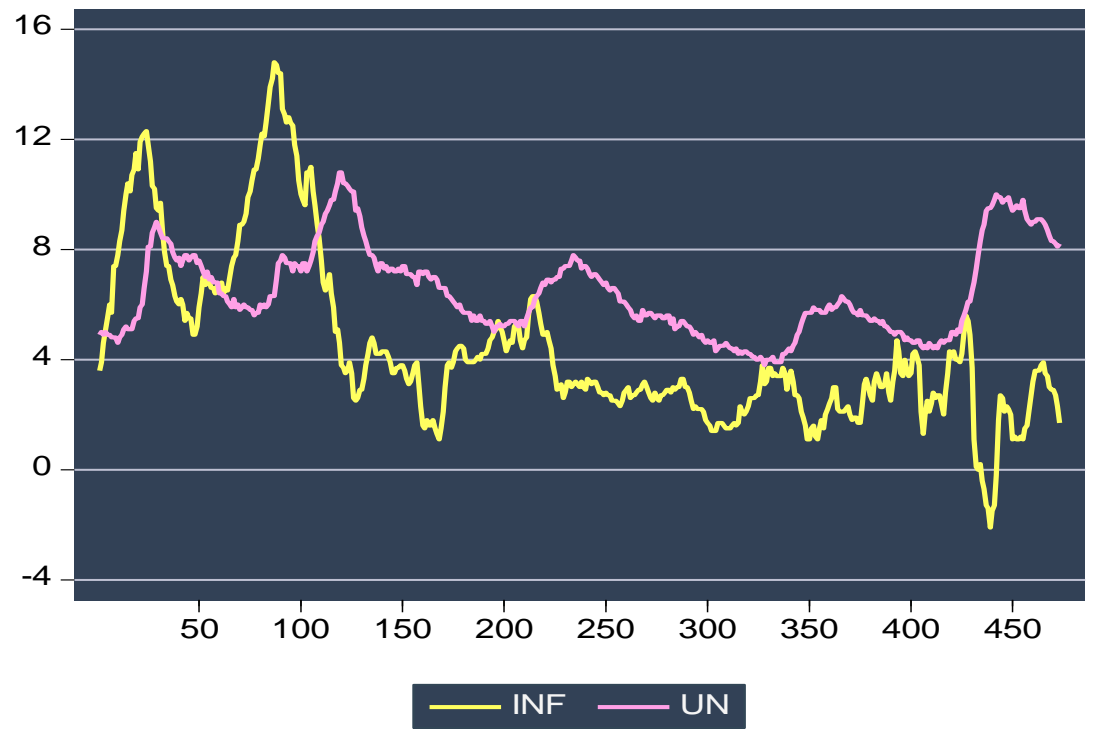

Figure 1. Inflation and unemployment trade off 


\subsection{Unit Root Test of the Residual for Testing Co-Integration}

We will now test the residual by an ADF unit root test. The purpose of conducting the test is to find stationary residual. A stationary residual will mean that the variables are co integrated. So our null $\left(H_{0}\right)$ is residual has a unit root. We want to reject the null $\left(H_{0}\right)$.

\begin{tabular}{|c|c|c|c|}
\hline \multicolumn{4}{|c|}{$\begin{array}{l}\text { Null Hypothesis: RESIDUAL has a unit root } \\
\text { Lag Length: } 12 \text { (Automatic based on SIC, MAXLAG=17) }\end{array}$} \\
\hline & & t-Statistic & Prob.* \\
\hline \multicolumn{2}{|c|}{ Augmented Dickey-Fuller test statistic } & -7.290442 & 0.0000 \\
\hline \multirow[t]{3}{*}{ Test critical values: } & $1 \%$ level & -3.444373 & \\
\hline & $5 \%$ level & -2.867617 & \\
\hline & $10 \%$ level & -2.570070 & \\
\hline
\end{tabular}

*MacKinnon (1996) one-sided p-values.

The result indicates us that we can reject the null $\left(H_{0}\right)$ at $5 \%$ level. So the residual series is stationary. It means that the variables are co integrated.

\subsection{Correlation Test of the Independent Variable to Detect Multicollinearity}

In this subsection we examine the correlation between the independent variable to check the multicollinearity. The correlation examination is important for us because here in our model we take the lagged value of inflation as an independent variable. So if the correlation coefficient becomes high it will indicate that there is multicollinearity between the independent variables. This might cause serious problem. So if the value of the correlation coefficient comes out high, we have to mitigate multicollinearity. We can do so by avoiding a variable from the model which has a higher probability and higher correlation coefficient. But if the correlation coefficient is low we need not to be worried about.

\begin{tabular}{lcc}
\hline & UN & INF_LAG \\
\hline UN & 1.000000 & 0.097951 \\
INF_LAG & 0.097951 & 1.000000 \\
\hline
\end{tabular}

Table: correlation coefficient between unemployment and lagged value of inflation in U.S.A

We can see that the correlation coefficient between unemployment and inflation lag is 0.097951 , which is not too high. It means the problem of multicollinearity is absent.

\subsection{Ramsey's RESET Test}

Now we test the adequacy of the model. There are many tests available to test the stability. But we will approach by the Ramsey RESET test. The following results are found.

\begin{tabular}{|c|c|c|c|c|}
\hline \multicolumn{5}{|l|}{ Ramsey RESET Test: } \\
\hline$\overline{\text { F-statistic }}$ & 3.592210 & \multicolumn{2}{|c|}{ Prob. F(1,468) } & 0.0587 \\
\hline Log likelihood ratio & 3.609079 & \multicolumn{2}{|c|}{ Prob. Chi-Square(1) } & 0.0575 \\
\hline \multicolumn{5}{|l|}{ Test Equation: } \\
\hline \multicolumn{5}{|c|}{ Dependent Variable: inflation } \\
\hline Variable & Coefficient & Std. Error & $\mathrm{t}$-Statistic & Prob. \\
\hline $\mathrm{C}$ & 0.404686 & 0.097271 & 4.160386 & 0.0000 \\
\hline UN & -0.045921 & 0.012147 & -3.780474 & 0.0002 \\
\hline INF_LAG & 0.954455 & 0.021532 & 44.32766 & 0.0000 \\
\hline FITTED^2 & 0.003058 & 0.001614 & 1.895313 & 0.0587 \\
\hline R-squared & 0.981785 & \multicolumn{2}{|c|}{ Mean dependent var } & 4.436229 \\
\hline Adjusted R-squared & 0.981668 & \multicolumn{2}{|c|}{ S.D. dependent var } & 3.095127 \\
\hline S.E. of regression & 0.419063 & \multicolumn{2}{|c|}{ Akaike info criterion } & 1.106846 \\
\hline Sum squared resid & 82.18714 & \multicolumn{2}{|c|}{ Schwarz criterion } & 1.142075 \\
\hline Log likelihood & -257.2157 & \multicolumn{2}{|c|}{ Hannan-Quinn criter. } & 1.120703 \\
\hline F-statistic & 8408.431 & \multirow{2}{*}{\multicolumn{2}{|c|}{ Durbin-Watson stat }} & 1.257783 \\
\hline Prob(F-statistic) & 0.000000 & & & \\
\hline
\end{tabular}

The Ramsey RESET test tells us that the model is correctly specified. The null $\left(H_{0}\right)$ in Ramsey RESET test is there is no mis-specification in the model. So our target is to accept the null $\left(H_{0}\right)$. And we in this test we cannot reject the null $\left(H_{0}\right)$ at $5 \%$ level. So there is no misspecification in this model. So, From the result of our estimation we can conclude that there is a long run trade of between rate of inflation and the rate of unemployment in U.S.A. and as we go through necessary statistical test we also can say that the result and the model is quite significant. The relation is depicted in the following figure. 


\section{Conclusion}

Empirical results of the paper give several points worth noting. In the light of empirical evidence, we have observed a clear long run trade-off relationship between the rate of inflation and the rate of unemployment by using both monthly and yearly data. It means there is a negative association between these two macroeconomic variables in the long run. A linear form of the Phillips curve is estimated using ordinary least squares estimation (OLS) approach. The co integration test shows long run relation between the variables. This rules out the possibility of vertical shape of Phillips Curve in the long run. Availability of better data set, the influence of previous inflation on current inflation and the existence of original Phillips relation in the long run provide incentives for further research on the present issue.

\section{References}

Alvaro, A., \& Manuel, M. (2005). Testing the significance and the non-linearity of the Phillips trade-off in the Euro Area. Empirical Economics, 30, 665-691. https://doi.org/10.1007/s00181-005-0250-z

Atkeson, A., \& Ohanian, L. E. (2001). Are Phillips Curves Useful for Forecasting Inflation. Federal Reserve Bank of Minneapolis Quarterly Review, 25(1), 2-11.

Branson, W. H. (1994). Macroeconomic theory and policy. $3^{\text {rd }}$ edition, Indus, 495-515.

Daly, M. C., \& Hobijn, B. (2014). Downward nominal wage rigidities bend the Phillips curve.

Dornbusch, R., Fischer, S., \& Startz, R. (2006). Macroeconomics", 9th edition, Mc Graw Hill, 116-138.

Dua, P., \& Gaur, U. (2009). Determinatiom of inflation in an open economy Phillips curve framework: The case of developed and developing asian countries", paper no 178.

Eliasson, A.C. (2001). Is the Short-run Phillips Curve Nonlinear? Empirical Evidence for Australia, Sweden and the United States. Sveriges Riksbank, Working Paper Series. No. 124.

Fair, R. C. (2012). Inflation and Unemployment in a Macro econometric Model, 164-193.

Friedman, M. (1970). Monerytary Statistics of the United States: Estimates, Sources, Methods. New York, Columbia University for the NBBR.

Fuhrer, J., \& Geoffrey, M. (1995). Inflation persistence. Quarterly Journal of Economics, 110(1). https://doi.org/10.2307/2118513

Furuoka, F. (2007). Does the phillips curve really exist? New empirical evidence from Malaysia. Economics Bulletin, 5(16), 1-14.

Gordon, R. J. (1990). U.S. Inflation labor's share and the natural rate of unemployment. Economics of wage determination, 1-34. New York: springer verlag.

Greenidge, K., \& DaCosta, D. (2009). Determinants of Inflation in selected countries business,Finance \&Economics in emergency. Economics, 4(2).

Gregor, W. S. (2006). Japan's Phillips curve looks like japan. Department of Economics, Queen's University, Canada.

Gruen, D., Pagan, A., \& Thompson (1999-2001). The Phillips curve in Australia. Research Discussion Paper". Economic research dept. Reserve bank of Australia.

Gujarati, D. N. (2005). Basic Econometrics, $4^{\text {th }}$ edition,Tata McGraw-Hill, 792-830.

Hasan, M. M. (2012). Searching for a Phillips curve for Bangladesh: An Econometrics Analysis. International Journal of African Studies.

Hill, R. C., Griffiths, W. E., \& lim, G. C. (2007). Principles of Econometrics. $3^{\text {rd }}$ edition.

Jeffrey, C. F. (1995). The Phillips Curve Is Alive As Well. New England Economic Review.

Katria, S., Bhutto, A. N., Butt, F., Domki, A. A., Khawaja, H. A., \& Khalid, J. Is There Any Tradeoff Between Inflation And Unemployment? The Case of SAARC Countries. Sukkur Institute of Business Administration, Proceedings of 62nd International Conference on Business Managemen . ISBN: 978-969-9368-06-6

King, R. G., \& Watson, M. W. (1994). The post-war U.S. Phillips curve: A Revisionist econometric history. Carnegie-Rochester Conference Series on Public Policy, 41, 157-219. https://doi.org/10.1016/0167-2231(94)00018-2

Koop, G., \& Onorante, L. (2012). Estimating Phillips curve in turbulent times using the ECB's survey of 
professional forcasters. Working paper series no-1422.

Kumar, A., \& Pia, O. (2015). Acloser look at the Phillips curve using state-level data.

Llaudes. R. (2005). The Phillips curve and long term unemployment. Working paper series no 441.Lucas, R., E., Jr. (1976), "Econometric Policy Evaluation: A Critique In The Phillips Curve and Labor Markets".

McConnell, B. (2008). Economics Principles.17th Edition.

Neugart, U., \& Hassler. M. (2003). "Inflation-unemployment tradeoff and regional labor market data. Empirical Economics, 28, 312-324.

Norman, D., \& Richards, A. (2010). Modelling inflation in Australia”, RDP 2010-03, Reserve Bank of Australia.

Perry, G. L. (1966). Unemployment, Money Wage Rates, and Inflation. Cambridge, the M.I.T. Press.

Phillips, A. W. (1958). The relationship between unemployment and the rate of change money wages in the united kingdom, 1861-1957. Economica, 25(100), 283-299.

Qin, D. (2010). Modeling of the inflation-unemployment trade off from the perspective of the history of economics, 1, ISSN 1473-0278.

Shadman, F. M. (1996). Does Modern Econometrics Replicate The Phillips Curve? IRES, Universit'e Catholique de Louvain.

Solow, R. M., \& Samuelson, P. A. (1960). Analytical Aspects of Anti-inflation Policy. American economic review, 177-194.

Subhani, M., Imtiaz, O., \& Amber, N. M. (2011). The South Asian Phillips Curve: Assessing the Gordon Triangle. European Journal of Economics Finance and Administrative science, 114(36), 110

Tino, B. (2011). Estimating Europe's natural rates. Empirical Economics, 40, 521-536. https://doi.org/10.1007/s00181-010-0342-2

\section{Web Sources:}

Labor Force Statistics from the Current Population Survey, retrieved from www.cia.gov, (1973-2012)

Historical-inflation-rates, retrieved from www.usinflationcalculator.com, (1973-2012)

\section{Copyrights}

Copyright for this article is retained by the author(s), with first publication rights granted to the journal.

This is an open-access article distributed under the terms and conditions of the Creative Commons Attribution license (http://creativecommons.org/licenses/by/4.0/). 